Review article

\title{
Communism and environmentalism: a doctrine-based review of similarities and differences
}

\author{
Alexandru-Ionuţ Petrişor ${ }^{1, \otimes}$ \\ "Ion Mincu" University of Architecture and Urban Planning, Romania
}

\begin{abstract}
The article is a review of the similarities and differences between the communist and environmentalist doctrines and their relationship. There are three pillars of the analysis: ideology, outcomes and a joint perspective. Ideologically, the division between 'leftist' and others with respect to their attitude towards the environment is based on the existence of fewer similarities than differences; the latter include the central organizing concepts, and perspectives on economy, technology, decentralization, and human nature. Based on the analysis, several categories can be distinguished: (1) socialists who see the unity; (2) environmentalists who see the unity, but do no require any change to socialism; (3) specialists sympathetic with both perspectives, who see the need for an evolution of socialism; and (4) environmentalists who are not socialists. The environmental outcomes of communist regimes are caused by the Marxist ideology: "man must rule and transform the nature". Therefore, capitalism is seen as a cause of environmental issues, and socialism as a common solution of both crises. They include the rapid industrialization, a state ownership of lands, and the lack of environmental law enforcement. Moreover, socialists deny the existence of an environmental crisis. Finally, the joint perspective reveals the fact that an opposition between industry and conservation is also present in capitalism.
\end{abstract}

Keywords: communism, socialism, ethics, environmentalism, attitudes, policies

\section{Introduction}

The communist regime affected the environment through the development of a polluting and resource-consuming industry, and change of agricultural practices (extensive development replacing natural ecosystems, and intensive development resulting into pollution with pesticides and fertilizers), significant land use

\footnotetext{
CORRESPONDENCE:

$\triangle$ Str. Academiei nr. 18-20, sector 1, cod 010014, Bucharest, Romania.

@@alexandru.petrisor@uauim.ro
} 
transformations (Filip and Cocean, 2012; Ianoş et al., 2012), over-harvesting of natural resources, or construction of dams and irrigation systems.

The question we are trying to answer in this paper relates to the relationship between communism and the environmental policy. Although the issue discussed in this article has been of interest for researchers for a long period, the literature on this topic is overall relatively scarce and in many cases opinions are in evident disagreement. Moreover, the recent literature is very rare; it seems that the topic does no longer receive the scientific interest which it used to have before the fall of communism.

\section{Communism and environmentalism}

Some of the authors had a particular interest in the ideological issues, while others focused, in a similar way to this paper, on the real-world effects of shifting ideologies; there are some papers that discuss both perspectives. Within the first category, there is a huge division between 'leftist' authors and the others.

When looking at the compatibility between environmentalism and communism, some authors tend to see the similarities: Adams et al. (2006) consider that greens, social-democratic and communists constitute the left block; his arguments are supported by Tranter (1999), who shows that green activism and voting also tends to be associated with the 'left' in Australia. Furthermore, Neumayer (2004) concludes that left-wing parties and individuals are also more proenvironmental than their right-wing counterparts, and ecological economics is more likely to be supported by left-wing parties and individuals. On a similar note, Paehlke (1986) adds that many North American environmentalists have come to appreciate socialism, and many socialists have sought a more sophisticated understanding of environmentalism.

Pepper (1985) also considers that the green movement is increasingly compatible with socialism, but makes a fine-tuned difference between the ideologies of the 'Green' and 'Red' wings of environmentalism; Green Greens are idealistic, and call for unity and spiritually-inspired value changes, while Green Reds are more realistic because their analysis is materialist. A similar distinction is made by Paehlke (1986), who shows that political ecology in the US is a more or less middle-class political movement aimed at providing quick technological fixes, and concerned with dietary habits; nevertheless, this ideology does not know who the enemy is or who its friends are.

Gale (1983) believes that the left could provide a theoretical context for environmental issues and influence the environmental movement emphasizing protest strategies and differential economic impacts of environmental problems. 
Based on an extensive review, Paehlke (1986) identifies several categories: (a) socialists who see the unity - socialism ensures environmental protection; (b) environmentalists who see many similarities with socialism, with little need to alter the later; (c) others are sympathetic with both ideologies, but find a need for a considerable evolution on the part of socialism; and (d) environmentalists who are clearly not socialists. The differences between environmentalism and socialism, pointed out also by Paehlke (1986), consist of the views on the central organizing concepts, economy, technology, decentralization and human nature.

\section{Communist attitudes towards the environment}

The attitude of 'leftist' authors towards the environmental outcomes of communism contrasts with the previous one; most of them almost deny the existence of an environmental crisis in socialist countries or as a consequence of the regime.

Pryde (1985) attempts to present an image of an 'environmentalist' Soviet Russia; ideologically, he shows that the pre-communist love of land (owned by people) did not imply a positive attitude towards conservation, and the confiscation of land actually made conservation possible. With respect to the environmental attitude, the author considers that there was a gradual shift from pure environmentalism (Lenin appointed environmentalists to key government positions) to Stalin's official utilitarian attitude toward the environment and later to a new era of environmental awareness starting in the 1960's.

Burkett (2005) argues extensively for Marx's vision of 'sustainable human development'. Mundey (1976) believes that Australian communists are among the few to trust in the global ecological crisis, while environmentalists have liberal and 'reactionary' ideas.

An important issue debated by many articles is whether the 'left' has embedded any concerns for the environment. Mazursky (1991) considers that the roots of environmental degradation in communism are in the Marxist ideology: man must rule and transform the nature; the natural resources are free and have no intrinsic value (in fact, they are valued through work).

Similarly, Khabibullov (1991) shows that environmental problems are inherent failures of the existing state system, especially due to the one-dimensional communist thinking. Farago (1985) argues for an integration of environmental issues by Marxists, while Mundey (1976) believes that Australian communists have already done it.

Paehlke (1986), Harribey (2008) and Gare (1993) partially agree on seeing capitalism as a cause of environmental issues; since the crises of environment and capitalism coincide, socialism is their common solution. A similar perspective is 
provided by Latouche (1989) who points out the similarity of the two when seeing nature as a commodity.

\section{Consequences of changing the political regimes}

When trying to explain the environmental outcomes of shifting to communism, opinions differ. Ziegler (1985) believes that different ideologies account for the varied images of the environment. Khabibullov (1991) considers that the processes started under the communists ideology and determining the degradation of the environment were the rapid industrialization, state ownership of lands and other natural resources, the lack of financial independence stopping environmental incentives, the expenditures policy, resulting into the impossibility of applying the 'polluter pays' principle, the leftovers policy of investments into environment, the measures focused on correction instead of prevention, the primitive technology, the fact that laws were not enforced, the structure of the administrative control of resources and the low environmental awareness and lack of public movements and participation.

Some of them are reiterated by other authors: Mazursky (1991) mentions the lack of information on environmental degradation and absence of law enforcement; Ostergren and Jacques (2002) account for the depletion of resources and pollution, but also on the lack of laws (the first appeared after 1980) and - similar to Earnhart (1997) - enforcement (laws were merely setting goals rather than providing means of control).

Glassheim (2006) accounts for environmental disaster among the many failures of communism, considering that there are ideological causes (worldly possessions privileged over non-economic values, heavy-industrial push) and practical causes - communist economic priorities explain the failure to stop pollution, because people and nature were subjugated to the demands of the production process; Glassheim (2006) believes that the environmental and social devastation in Bohemia is also due to the fact that the area was seen as a laboratory during the communist regime; and Weissenburger (1987) shows that the environmental protection goals were not achieved after 1975. Jehlicka (2003) shows that, as a consequence of communist ideologies, Visegrad countries are not likely to support the European Union environmental policies; moreover, restrictions in consumption by communism lead to a negative environmental attitude when the consumption of resources is no longer restricted by the democratic regime.

A different perspective given by Goldman (1970), considering that industrialization, and not private enterprises, causes environmental disruption and strongly centralized planned economies do not necessarily avoid the contamination of the environment. Similarly, Glassheim (2006) shows that the opposition between 
industrial / production and environmental / conservation interests exists even in capitalism.

\section{Ethical perspectives}

Modern ethical concerns on animals, species and the environment have addressed a variety of issues, including the general attitude towards the environment, environmental values, sharing and distribution of natural resources, morality of hunting, animal slaughtering or killing, or use in tests, feral animals (Loftin, 1984; Shelton, 2004; Bărbulescu and Andreescu, 2010; Marinescu and Coman, 2010; Iojă et al., 2011; Papuziński, 2016; Rydzewski, 2016; Christmas, 2017; Turnpenny and Russel, 2017; Dzwonkowska, 2018; Ivanova, 2018; Singh, 2018), but also interference with the natural laws (Taylor, 1981; Mittelstra, 2003) through human activities, developed consciously or not (Scott, 1973; Scripcaru et al., 2004; Bredetean, 2006; Petrişor, 2006; Ehrilich, 2009).

The main beliefs substantiating these attitudes are that humans and wildlife are members of the Earth's Community of life, are integral elements in a system of interdependence, are teleological centers of file, species have an intrinsic value, humans are not inherently superior to other species (Taylor, 1981; Montagu, 1986; Schmidtz, 1998; Scripcaru et al., 2004; Ehrilich, 2009; Gola, 2009) and their consequence is an expansion of the moral duty to wildlife in addition to humans (Lynn, 2010).

Current ethical concerns are focused on reducing the suffering of animals put to an end (Loftin, 1984; Bărbulescu and Andreescu, 2010; Marinescu and Coman, 2010); at a higher level, man has no right to tackle with the ecosystem laws (Taylor, 1981; Loftin, 1984; Mittelstra, 2003; Horta, 2010; Gache, 2013) and certainly no right to determine the extinction of species (Scott, 1973). The moral question concerns the fact that humans and wildlife are co-sharers of the Planet's resources (Schmidtz, 1998) and therefore our attitude should be of respect (Taylor, 1981; Schmidtz, 1998; Lodge and Shrader-Frechette, 2003; Scripcaru et al., 2004; Ehrilich, 2009; Ianoş et al., 2009; Lynn, 2010), particularly since humans are conscious of their actions (Shelton, 2004).

The consequence should be a new type of environmental ethics (Scripcaru et al., 2004; Petrişor, 2006, 2007) substantiating a moral analysis of the final goals of intervention (Horta, 2010), and, more general, an application of the 'precautionary principle', due to the irreversibility of species loss (Mason et al., 2001; Humphrey, 2001).

\section{Conclusions}

In more general terms, the literature review suggests that there might be differences 
between the 'official' attitude of communists towards the environment, which could be more favorable to protection, and the practical implementation of policies. Furthermore, a consistent part of the literature blames capitalism for the environmental crises and considers that the greed for profit, especially during the early industrialization, is at its core and suggests that communist egalitarianism would not have the same consequences.

In general, the actual communist practices had a strong negative impact on the environment despite a declarative pro-environmentalist appearance.

\section{References}

Adams, J., Clark, M., Ezrow, L., Glasgow, G. (2006). Are Niche Parties Fundamentally Different from Mainstream Parties? The Causes and the Electoral Consequences of Western European Parties' Policy Shifts, 1976-1998. American Journal of Political Science, 50(3), 513-529, Wiley-Blackwell, Hoboken, NJ, USA.

BăRbulescu, I., Andreescu, G. (2010). Animal stunning, the EU, and the Romanian lobby. Romanian Journal of Bioethics, 8(1), 190-199, Romanian College of Physicians, Iaşi, Romania.

BREDETEAN, V. (2006). Bioethics, the 'younger sister' of ecology? Romanian Journal of Bioethics, 4(1), 1-3, Romanian College of Physicians, Iaşi, Romania.

BuRKeTT, P. (2005). Marx's vision of communism and sustainable human development. Monthly Review. An Independent Socialist Magazine, 57(5), 34-57, Monthly Review Foundation, New York, NY, USA.

CHRISTMAS, B. (2017). Incommensurability and property rights in the natural environment. Environmental Politics, 26(3), 502-520, Taylor \& Francis, Milton Park, Didcot, UK.

DzWONKOWSKA, D. (2018). Environmental Virtue Ethics and Sustainability. Problemy Ekorozwoju - Problems of Sustainable Development, 13(2), 139-146, European Academy of Science and Arts, Salzburg, Austria.

EARNHART, D. (1997). Enforcement of environmental protection laws under communism and democracy. The Journal of Law and Economics, 40(2), 377-402, The University of Chicago Press, Chicago, IL, USA.

EHRILICH, P. R. (2009). Ecoethics: Now central to all ethics. Bioethical Inquiry, 6(4), 417-436, Springer, Berlin, Germany.

FARAGO, A. (1985). Environmentalism and the Left. Urban Policy and Research, 3(3), 11-15, Taylor \& Francis, Milton Park, Didcot, UK.

FILIP, S., COCEAN, P. (2012). Urban industrial brownfields: constraints and opportunities in Romania. Carpathian Journal of Earth and Environmental Sciences, 7(4), 165-174, North University of Baia Mare Press, Baia Mare, Romania.

GACHE, C. (2013). Environmental ethic values through ecological education in one Romanian master degree program. Natura Montenegrina, 12(3-4), 1-8, Sjedište Museum, Trg Bećirbega, Montenegro.

Gale, R. P. (1983). The Environmental Movement and the Left: Antagonists or Allies? Sociological Inquiry, 53(2-3), 179-195, Wiley-Blackwell, Hoboken, NJ, USA. 
GARE, A. (1993). Soviet environmentalism: The path not taken. Capitalism Nature Socialism, 4(4), 69-98, Taylor \& Francis, Milton Park, Didcot, UK.

GlassheiM, E. (2006). Ethnic Cleansing, Communism, and Environmental Devastation in Czechoslovakia's Borderlands, 1945-1989. The Journal of Modern History, 78(1), 65-92, The University of Chicago Press, Chicago, IL, USA.

GolA, B. G. (2013). Ecological ethics as the basis for the philosophy of ecological upbringing. Kultura $i$ Wychowanie, 5(1), 48-55, Akademia Humanistyczno-Ekonomiczna w Łodz, Łodz, Poland.

Goldman, M. I. (1970). The Convergence of Environmental Disruption. Science, 170(3953), 3742, American Association for the Advancement of Science, Washington, DC, USA.

Harribey, J.-M. (2008). Ecological Marxism or Marxian Political Ecology, in: BIDET, J., KOUvelaKIS, S. (Eds.), Critical Companion to Contemporary Marxism, Brill, Leiden, The Netherlands, pp. 189-208.

HORTA, O. (2010). The ethics of the ecology of fear against the nonspeciesist paradigm: a shift in the aims of intervention in nature. Between the Species, 13(10), 163-187, California Polytechnic State University, San Luis Obispo, CA, USA.

Humphrey, M. (2001). Three conceptions of irreversibility and environmental ethics: some problems. Political Theory and the Environment, 10(1), 138-154, Oxford University Press, Oxford, UK.

IANOS, I., PePtenAtU, D., ZAMFIR, D. (2009). Respect for environment and sustainable development. Carpathian Journal of Earth and Environmental Sciences, 4(1), 81-93, North University of Baia Mare Press, Baia Mare, Romania.

IANOŞ, I., SîRODOEV, I., PASCARIU, G. (2012). Land-use conflicts and environmental policies in two post-socialist urban agglomerations: Bucharest and Chişinău. Carpathian Journal of Earth and Environmental Sciences, 7(4), 125-136, North University of Baia Mare Press, Baia Mare, Romania.

IojĂ, I. C., Rozylowicz, L., PĂtroescu, M., Niță, M. R., VÂNĂU, G. O. (2011). Dog walkers' vs. other park visitors' perceptions: The importance of planning sustainable urban parks in Bucharest, Romania. Landscape and Urban Planning, 103(1), 74-82, Elsevier, New York, NY, USA.

Ivanova, S. (2018). Some Legal Problems Concerning Implementation of Sustainable Use of Wildlife Concept in the Russian Federation. Problemy Ekorozwoju - Problems of Sustainable Development, 13(2), 147-156, European Academy of Science and Arts, Salzburg, Austria.

JehlickA, P. (2003). The Myth of the End of Progressive Environmental Policy. Ökologisches Wirtschaften, 18(1), 24-25, Institut für ökologische Wirtschaftsforschung, Berlin, Germany.

Khabibullov, M. (1991). Crisis in Environmental Management of the Soviet Union. Environmental Management, 15(6), 749-763, Springer, Berlin, Germany.

LATOUCHE, S. (1989). L'occidentalisation du monde. Essai sur la signification, la portée et les limites de l'uniformisation planétaire, La Découverte, Paris, France, 141 pp.

LOdGE, D. M., SHRADER-FreCHETTE, K. (2003). Nonindigenous species: ecological explanation, environmental ethics, and public policy. Conservation Biology, 17(1), 31-37, WileyBlackwell, Hoboken, NJ, USA. 
LOfTIN, R. W. (1984). The Morality of Hunting. Environmental Ethics, 6(3), 241-250, University of North Texas, Denton, TX, USA.

LYNN, W. S. (2010). Discourse and Wolves: Science, Society, and Ethics. Society and Animals, 18(1), 75-92, Koninklijke Brill NV, Leiden, The Netherlands.

MARINESCU, B., COMAN, C. (2010). The ethics of animals testing. Romanian Journal of Bioethics, 8(3), 197-204, Romanian College of Physicians, Iaşi, Romania.

MASON, J. R., SHIVIK, J. A., FALL M. W. (2001). Chemical repellents and other aversive strategies in predation management. Endangered Species Update, 18(4), 175-181, University of Michigan, MI, USA.

MAZURSKY, K. R. (1991). Communism and the Environment. Forum for Applied Research and Public Policy, 5(4), 39-44, University of Tennessee, Knoxville, TN, USA.

MitTelstRA, J. (2003). The impact of the new biology on ethics. Romanian Journal of Bioethics, 1(2), 1-8, Romanian College of Physicians, Iaşi, Romania.

MontAGU, A. (1986). Humans and other animals: A biological and ethical perspective, in: Fox, M. W., MicKleY, L. D. (Eds.), Advances in animal welfare science 1986/87, The Humane Society of the United States, Washington, DC, pp. 165-177.

Mundey, J. (1976). Ecology, Capitalism, Communism. Australian Left Review, 1(51), 30-34, Communist Party of Australia, Canberra, Australia.

NeUMAYER, E. (2004). The environment, left-wing political orientation and ecological economics. Ecological Economics, 51(3-4), 167-175, Elsevier, New York, NY, USA.

Ostergren, D., Jacques P.(2002). A Political Economy of Russian Nature Conservation Policy: Why Scientists have Taken a Back Seat. Global Environmental Politics, 2(4), 102-124, MIT Press, Cambridge, MA, USA.

PAEHLKE, R. (1986). Environmentalism and the Left in North America. A Comment. Studies in Political Economy, 16(1), 143-151, Taylor \& Francis, Milton Park, Didcot, UK.

PAPUZIŃSKI, A. (2016). Environmental Ethics as Ethics of the Political State. Problemy Ekorozwoju - Problems of Sustainable Development, 11(2), 23-28, European Academy of Science and Arts, Salzburg, Austria.

PEPPER, D. (1985). Determinism, idealism and the politics of environmentalism - a view point. International Journal of Environmental Studies, 26(1-2), 11-19, Taylor \& Francis, Milton Park, Didcot, UK.

PETRIŞOR, A.-I. (2006). Ecology and orthodox theology. Romanian Journal of Bioethics, 4(2), 8291, Romanian College of Physicians, Iaşi, Romania.

PETRIŞOR, A.-I. (2007). Looking at deterioration of the environment. Romanian Journal of Bioethics, 5(3), 62-66, Romanian College of Physicians, Iaşi, Romania.

PRYDE, P. R. (1985). Culture and the Environment in the Soviet Union. Environmental Management, 9(2), 151-160, Springer, Berlin, Germany.

RYDZEWSKI, P. (2016). Changes in Environmental Attitudes in Selected Countries of Central and Eastern Europe. Problemy Ekorozwoju - Problems of Sustainable Development, 11(1), 65-72, European Academy of Science and Arts, Salzburg, Austria.

SCHMIDTZ, D. (1998). Are all species equal? Journal of Applied Philosophy, 15(1), 57-67, WileyBlackwell, Hoboken, NJ, USA.

ScotT, P. SIR. (1973). Species Extinction in Birds. Bird Study, 20(2), 93-102, Taylor \& Francis, Milton Park, Didcot, UK. 
SCripCARU, G., AStarastoae, V., ISAC, L. (2004). Bioethics and ecology. Romanian Journal of Bioethics, 2(3), 1-5, Romanian College of Physicians, Iaşi, Romania.

SHELTON, J. A. (2004). Killing animals that don't fit in: moral dimensions of habitat restoration. Between the Species, 13(4), 1-16, California Polytechnic State University, San Luis Obispo, CA, USA.

SINGH, M. (2018). Equality of Resources, Ethical Principles and Sustainable Development. Problemy Ekorozwoju - Problems of Sustainable Development, 13(2), 185-190, European Academy of Science and Arts, Salzburg, Austria.

TAYLOR, P. W. (1981). The ethics of respect for nature. Environmental Ethics, 3(3), 197-218, University of North Texas, Denton, TX, USA.

TURNPENNY, J. R., RUSSEL, D. J. (2017). The idea(s) of 'valuing nature': insights from the UK's ecosystem services framework. Environmental Politics, 26(6), 973-993, Taylor \& Francis, Milton Park, Didcot, UK.

TRANTER, B. (1999). Environmentalism in Australia: elites and the public. Journal of Sociology, 35(3), 331-350, SAGE Publishing, Thousand Oaks, CA, USA.

WEISSENBURGER, U. (1987). Environmental protection in the USSR. Economic Bulletin, 23(11), 611, Springer, Berlin, Germany.

ZIEGLER, C. E. (1985). Soviet Images of the Environment. British Journal of Political Science, 15(3), 365-380, Cambridge University Press, Cambridge, UK. 
